\title{
Biological Control of Pythium aphanidermatum, the Causal Agent of Tomato Root Rot by Two Streptomyces Root Symbionts
}

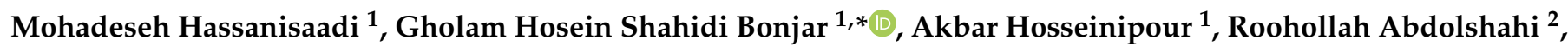 \\ Essaid Ait Barka ${ }^{3}$ iD and Ismail Saadoun ${ }^{4}$ \\ 1 Department of Plant Protection, Shahid Bahonar University of Kerman, Kerman 7618411764, Iran; \\ mhassani@agr.uk.ac.ir (M.H.); Hosseini@uk.ac.ir (A.H.) \\ 2 Department of Agronomy and Plant Breeding, Shahid Bahonar University of Kerman, \\ Kerman 7618411764, Iran; abdoshahi@uk.ac.ir \\ 3 Induced Resistance and Plant BioProtection Research Unit, UFR Sciences, UPRES EA 4707, \\ Université de Reims Champagne-Ardenne, 51687 Reims, France; ea.barka@univ-reims.fr \\ 4 Department of Applied Biology, College of Sciences, University of Sharjah, \\ Sharjah P. O. Box 27272, United Arab Emirates; isaadoun@sharjah.ac.ae \\ * Correspondence: shahidi@uk.ac.ir
}

check for updates

Citation: Hassanisaadi, M.; Shahidi Bonjar, G.H.; Hosseinipour, A.; Abdolshahi, R.; Ait Barka, E.; Saadoun, I. Biological Control of Pythium aphanidermatum, the Causal Agent of Tomato Root Rot by Two Streptomyces Root Symbionts. Agronomy 2021, 11, 846. https:// doi.org/10.3390/agronomy11050846

Academic Editor: Diego Rubiales

Received: 22 March 2021

Accepted: 17 April 2021

Published: 26 April 2021

Publisher's Note: MDPI stays neutral with regard to jurisdictional claims in published maps and institutional affiliations.

Copyright: (c) 2021 by the authors. Licensee MDPI, Basel, Switzerland. This article is an open access article distributed under the terms and conditions of the Creative Commons Attribution (CC BY) license (https:/ / creativecommons.org/licenses/by/ $4.0 /)$.

\begin{abstract}
Damping-off caused by Pythium aphanidermatum, as one of the most infamous plant diseases, is considered as a significant disease that causes severe damages in greenhouse and field crops in a vast range of hosts especially vegetables. The application of chemical fungicides as a common method to control this disease poses negative side effects on humans and the environmental components. Actinobacteria, especially members of the genus Streptomyces, are fascinating biocontrol agents and plant growth-promoting rhizobacteria, which exhibit safer alternative managements to control this disease. The present study aims to explore for bioactives soil Streptomyces isolates that are able to control $P$. aphanidermatum, which is the causal agent of damping-off in tomato. Out of a total of 116 actinobacteria isolates collected from the soil, 53 have showed an antagonistic activity against $P$. aphanidermatum, as deduced through in vitro dual cultures. Based on in vitro Petri plate seedlingbioassays (IPSB), from the 53 tested isolates in dual cultures, two isolates coded as $\mathrm{H} 2$ and H3, considered as the most bioactive agents, were selected to assess their biocontrol performances against P. aphanidermatum in the Sandwich bed-mix technique in greenhouse experiments. In vivo greenhouse statistical studies were performed to compare seven treatments using completely randomized design experiments. Metalaxyl fungicide was applied as the chemical-control treatment. To evaluate biocontrol efficiencies of the two Streptomyces symbionts, disease incidence recorded throughout the course of experiment and criteria of number of leaves, length of the plants, plant fresh and dry weights, were measured at the end of experiment and analyzed statistically. The resulted disease incidences for all treatments indicated that the two Streptomyces strains had PGPR activity, and they were effective in decreasing disease incidence and improving plant performances regarding number of leaves, height, and plant fresh and dry weights. Based on the phylogenetic analysis of the partial sequences of the 16S rRNA gene, the strain $\mathrm{H} 2$ revealed a close relation to six Streptomyces species, namely S. badius, S. caviscabies, S. globisporus, S. parvus, S. sindenensis, and S. griseoplanus, with 99.9\% similarity. The strain $\mathrm{H} 3$ also indicated a close relation of the same similarity to two species, namely S. flavogriseus and S. pratensis. In overall, collected data dictated that the two bioactive root symbiont Streptomyces strains effectively controlled the damping-off disease caused by P. aphanidermatum.
\end{abstract}

Keywords: Streptomyces; Pythium aphanidermatum; biocontrol; root symbionts; PGPR; 16S rRNA; tomato; damping-off; antagonist

\section{Introduction}

Tomato (Lycopersicon esculentum Mill, Solanaceae) is one of the most important vegetables in many countries with China, India, USA, Turkey, Egypt, Iran, Italy, Spain, Mexico, 
and Brazil as the top ten producers of tomato in the world. According to FAO recent reports, in 2018, Iran ranks sixth in the world with the production of over six million tons of tomatoes per year [1]. Many of the soil-borne pathogens threaten this crop and reduce its production efficiency. Damping-off is as one of the devastating soil-borne diseases that causes serious problems in tomato seedlings [2]. Pythium spp., Fusarium spp., Rhizoctonia spp., and Phytophthora spp. are as the most frequently plant pathogens associated with damping-off [3]. The Pythium spp. that are ubiquitous parasites in soil and water are considered as the most notorious plant pathogens in vegetables especially in the nursery, greenhouse, and field [4,5]. The most common species of Pythium in greenhouses include $P$. aphanidermatum (Edson) Fitzpatrick, P. ultimum, P. irregulare, P. myriotylum, P. spinosum, and P. splendens [6]. P. aphanidermatum, the most destructive species in the genus, is a frequent agent of damping-off and root rot of tomato in nurseries and greenhouses [7]. It causes rotting and imposes economic damages on many monocotyledon and dicotyledon plants such as members of the Solanaceae family [4]. Pythium aphanidermatum is also the causal agent of seed rot, seedling rot, root rot, cottony leak, stem, and rhizome rots as well as pre- and postemergence disorders in many other economic crops [8,9]. The pre-emergence damping-off symptoms have been associated with damage to seeds or seedlings before their emergence from the soil. Throughout the onset of pre-emergent damping-off rots, infection of the germinating seeds may result in seeds rot or produce water-soaked lesions on the roots and stems of emerging seedlings, ultimately leading to seedling death. In post-emergence, the damping-off occurs after young seedling emergence from the soil. At this stage, the stem becomes thin with brown lesions, the infected crown rots, the hypocotyl becomes water-soaked, the cotyledon leaves may roll downward, and the roots of infected plant rot; then, consequently, the plant dies $[10,11]$. Oospores, sporangia, and mycelia are surviving forms of P. aphanidermatum in the organic debris and soil $[5,12,13]$. To control this pathogen, several agricultural practices have been applied such as crop rotation, soil-solarization, and the use of chemical fungicides; however, none of them exhibit practicable and sustainable results in highly infected soils. Given the wide host range of this devastating pathogen and its prolonged survival in the soil, it is quite difficult to control the disease [7]. The fungicide metalaxyl has been shown to be very effective to manage the damping-off caused by Oomycetes and to lower the disease incidence. Nevertheless, several reports demonstrated metalaxyl, metalaxyl-M, and Mefenoxam resistance in Pythium spp. [14-16]. However, the use of chemical fungicides poses harmful side effects on humans and the environment $[17,18]$. Awareness of the short and long-term adverse effects of chemical pesticides has led to use of less calamitous approaches and alternative applications such as biological methods. Looking to forefront horizons, the biological methods are being seen as promising and sustainable methods to manage plants diseases. Under the light of such a view and the demand of the general public in recent decades, the biological control agents (BCAs) have been vastly employed to replace chemical agents for the control of plant pathogens. In this regard, several fungal and bacterial agents including Trichoderma $[19,20]$, non-pathogenic Fusarium [21], Xanthomonas, Serratia [22], Bacillus [23,24], Pseudomonas [25], and Streptomyces [26-29] have been reported as effective biological control agents. Furthermore, there are several reports on biological control agents of P. aphanidermatum in tomato specifically include Bacillus subtilis and Trichoderma spp. [20,30], Aspergillus terreus [31], Klebsiella oxytoca, Exiguobacterium indicum and Bacillus cereus [32], Talaromyces variabilis [33], and Streptomyces spp. isolate KUMB1.1 [34]. Some of these microorganisms also act as plant growth-promoting fungi (PGPF) or plant growth-promoting rhizobacteria (PGPR). For the first time, Kloepper and Schroth defined PGPRs as plant bacteria that are able to colonize plant roots and improve plant growth [35]. Among PGPRs, Streptomyces is the largest genus of phylum Actinobacteria and considered as the type genus of the family Streptomycetaceae with more than 500 species [36,37]. It has attracted a lot of attention regarding their ability to produce antibiotics and biologically active secondary metabolites, which make them the most bioactive microorganisms [38-40]. PGPRs can be applied effectively in the management of plant pathogenic fungi and bacteria [27]. Streptomyces 
species are saprophytic bacteria, with filamentous nature, Gram-positives, and high GC content in the genome (about $70 \%$ ) that can also play a role as symbiont bacteria with plants [41,42]. Streptomyces spp. are known as biological potential resources for producing more than $75 \%$ of bioactive substances and secondary metabolites including more than $80 \%$ of the world antibiotics [43-46]. A range of beneficial microorganisms, especially Streptomyces, can colonize plant roots in symbiotic interaction. Indeed, colonization is an important behavior in biocontrol interactions, and it can enable symbiont inoculants to compete with indigenous and deleterious microorganisms by competitive exclusion, because they can occupy ecological niches and use nutrients and space resources [47,48]. Loliama et al. [49] proved that Streptomyces species could be considered as effective candidates for the biocontrol of damping-off caused by P. aphanidermatum. In this regard, $S$. rubrolavendulae S4 was able to control P. aphanidermatum in Amaranthus tricolor seedlings as effectively as the fungicide metalaxyl. In another study, two endophytic Actinobacteria isolated from healthy maize plants, Streptomyces sp. 16R3B and Streptomyces sp. 14F1D/2, were able to reduce damping-off in cucumber under greenhouse conditions caused by $P$. aphanidermatum up to $71 \%$ and $36 \%$, respectively $[50,51]$. Consequently, in this research, we focused on in vitro screening and in vivo biocontrol of tomato root rot caused by $P$. aphanidermatum using potent Streptomyces spp. Objectives of this research were (1) to isolate biologically efficient Streptomyces species from soil and evaluation of their biological control performance against $P$. aphanidermatum in tomato plants; (2) to evaluate the tomato plant growth-promotion properties resulting from bacterial interaction; and (3) characterize and identify molecularly the bioactive Streptomyces isolates based on 16S rRNA sequence analyses.

\section{Materials and Methods}

\subsection{Culture Media and Preparation of the Pathogen}

Pure culture of P. aphanidermatum (accession no. MV599252) obtained from Mycology Laboratory, Department of Plant Protection, Faculty of Agriculture, University of Jiroft, Iran. The pathogen was cultured on potato dextrose agar (PDA, Merck, Darmstadt, Germany) and kept at ambient temperature before use.

\subsection{Pathogenicity Assessment}

To be assured of the pathogenicity of P. aphanidermatum on tomato seedlings (Lycopersicon esculentum cv. Moneymaker), damping-off incidence was assessed on tomato seedlings as described by Abreo et al. [52]. In this regard, tomato seeds treated with $2 \%$ sodium hypochlorite solution for one min, washed in three series of sterilized water for two min, then placed on $2 \%$ water agar (WA) Petri plates and kept in dark to germinate at ambient temperature. Four days later, a mycelial disc of six-millimeter diameter was cut with a sterile cork-borer and placed at the center of each Petri plate at equal distances from the seeds and incubated for 2 to 4 days at $25^{\circ} \mathrm{C}\left( \pm 2{ }^{\circ} \mathrm{C}\right)$. Control Petri plates received blank agar disks in the same manner.

\subsection{Soil Samples and Isolating Actinobacteria}

Twenty samples of rhizospheric soil were collected from different healthy-looking tomato fields located in different regions of Kerman province, Iran. The soil samples were dried in the shade for $24 \mathrm{~h}$, and bulk soil was removed by sieve shaking. One $\mathrm{g}$ of each soil sample was mixed with sterile distilled water at 1:10 ratio $(w / v)$, shaken vigorously for $10 \mathrm{~min}$, settled for $10 \mathrm{~min}$, and $1 \mathrm{~mL}$ aliquot of the suspension diluted by sterilized distilled water by 10 -fold series up to $10^{-6}$ dilution. To culture, aliquots of $1 \mathrm{~mL}$ of each of $10^{-3}, 10^{-4}, 10^{-5}$, and $10^{-6}$ dilutions mixed with aliquots of $20 \mathrm{~mL}$ of relatively cooled $\left(48-49^{\circ} \mathrm{C}\right.$ ) autoclaved Casein Glycerol Agar (CGA) medium, which was prepared from basic ingredients as described by Küster and Williams [53], in separate $12 \mathrm{~cm}$ Petri plates and let to solidify [54]. Two replicates were considered for each dilution. Plates were incubated at $28^{\circ} \mathrm{C}$ for a week. When Streptomyces colonies became visible, the aseptically 
streaking method [55] was used to get pure cultures of Streptomyces isolates on CGA slants. The pure Actinobacteria isolates were incubated at $28^{\circ} \mathrm{C}$ for 7 days and then refrigerated at $4{ }^{\circ} \mathrm{C}$ before use [56].

\subsection{In Vitro Screening of Actinobacteria}

To screen for anti-Pythium Actinobacteria, dual culture bioassays conducted as described by El-Tarabily et al. [57]. Briefly, plugs of 6-day-old actinobacterial isolates and one uninoculated medium plug (as control) cut with a sterile cork borer (diameter of $6 \mathrm{~mm}$ ) were placed at $2 \mathrm{~cm}$ distances from each other on each PDA Petri plate using a sterile forceps. After $48 \mathrm{~h}$ at $28^{\circ} \mathrm{C}$, a six mm plug from 3-day-old P. aphanidermatum was placed in the center of each PDA Petri plate and incubated at $28{ }^{\circ} \mathrm{C}$ for 3 days until the $P$. aphanidermatum colony margin of control reached close to the edge of the plate. The anti-Pythium activity of Actinobacteria isolates was determined as follows. Insertion of mean of growth radius of $P$. aphanidermatum in control $\left(\mathrm{r}_{1}\right)$ and mean of growth radius of $P$. aphanidermatum in dual culture bioassay $\left(r_{2}\right)$ in the following formula: $\Delta r=r_{1}-r_{2}$. The modified ratings were applied from El-Tarabily et al. [57]: where $\Delta \mathrm{r}>2$ and $<4 \mathrm{~mm}$, it was represented as +; where $\Delta \mathrm{r}>4$ and $<6 \mathrm{~mm}$, it was represented as ++ and where $\Delta \mathrm{r}>6 \mathrm{~mm}$, it was represented as +++ .

\subsection{In Vitro Petri Plate Seedling-Bioassay}

In vitro Petri plate seedling-bioassay (IPSB) is a bioassay technique we developed in our lab. To evaluate the potential ability of isolated actinobacteria to inhibit or suppress the pathogenicity of $P$. aphanidermatum in tomato seedlings, the isolated actinobacteria, showing promising results from in vitro dual culture bioassays, were meticulously evaluated in this experiment. In this regard, seeds surface were sterilized (two min in $2 \%$ sodium hypochlorite and subsequently $5 \mathrm{~min}$ rinse with sterilized distilled water) and placed on well-grown 6-day-old cultures of actinobacteria solid media and shaken until seeds were fully coated with spores. Coated seeds were placed near the margin of $2 \%$ WA Petri plates and then received a $6 \mathrm{~mm}$ plug of 3-day-old P. aphanidermatum culture at the center. To set controls, uncoated seeds and the pathogen were considered as positive controls and uncoated seeds with no pathogen, but a blank agar plug, were considered as negative controls. After a week on a lab bench at ambient temperature, seed rots and seedlings viability in the three treatments were recorded for the tested actinobacteria. All experiments were performed in triplicate, and mean values were recorded.

\subsection{In Vitro Root Colonization Bioassay}

To evaluate the ability of the active actinobacteria isolates for the colonization of tomato roots, the following steps were performed consecutively. The tomato seeds surface was sterilized ( $2 \mathrm{~min} 2 \%$ sodium hypochlorite, $5 \mathrm{~min}$ successive rinses with sterilized distilled water). The spore suspension of each actinobacteria isolate was prepared at concentrations of $10^{8} \mathrm{CFU} \mathrm{mL} \mathrm{mL}^{-1}$ by gentle scraping off the spores of the surfaces of 7 day-old cultures using sterile scalpels. Using a NanoDrop ${ }^{\mathrm{TM}}$ spectrophotometer (Thermo Scientific ${ }^{\mathrm{TM}} 840274200$ ), the final concentrations of spore suspensions were adjusted to OD: 1 at $660 \mathrm{~nm}$. For each isolate, the sterilized tomato seeds were immersed in the spore suspension and shaken for $30 \mathrm{~min}$. Subsequently, the inoculated seeds were placed on $2 \%$ WA Petri plates and incubated at ambient temperature $\left(25 \pm 2{ }^{\circ} \mathrm{C}\right)$ until germinated. When primary roots length reached about $4 \mathrm{~cm}$, approximately 4-6 mm of elongation zones of roots of each treatment was cut with a sterile scalpel, aseptically placed on CGA medium, and then incubated at $28{ }^{\circ} \mathrm{C}$ for 3-4 days in the dark at ambient temperature. The growth of actinobacteria at this experiment was considered as positive, and the lack of growth was negative root colonization. Positively root-colonized actinobacteria were considered as tomato root symbionts. All experiments were performed in triplicates and plates were inspected for the growth of actinobacteria daily. 


\subsection{DNA Extraction, PCR Amplification, and Electrophoresis}

The Streptomyces strains ( $\mathrm{H} 2$ and $\mathrm{H} 3)$ were cultured on the CGA medium and incubated at $28{ }^{\circ} \mathrm{C}$ for a week. Then, aerial mycelia were aseptically scraped off by sterile scalpels, and DNA was extracted by using the CTAB method [58]. For 16S rRNA gene amplification, the universal primers F1 (5'-AGAGTTTGATCITGGCTCAG-3') and R5 (5'ACGGITACCTTGTTACGACTT-3'; I = inosine) were used [59]. PCR was carried out in a thermal cycler (Biometra, T-Personal Thermal Cycler) with final volumes of $15 \mu \mathrm{L}$ containing 7.5 $\mu \mathrm{L} 2 \mathrm{X}$ PCR master mix (Parstous, Iran), $0.5 \mu \mathrm{M}$ of each of the primers, and 50 ng DNA template of each strain. The thermal conditions for amplification were: initial denaturation at $96^{\circ} \mathrm{C}$ for $2 \mathrm{~min}$, followed by 30 cycles of denaturation at $96{ }^{\circ} \mathrm{C}$ for $45 \mathrm{~s}$, annealing at $56{ }^{\circ} \mathrm{C}$ for $30 \mathrm{~s}$, and extension at $72{ }^{\circ} \mathrm{C}$ for $2 \mathrm{~min}$, and a final extension at $72{ }^{\circ} \mathrm{C}$ for $10 \mathrm{~min}$. Lastly, PCR products were electrophoresed on a $1 \%$ agarose gel containing $10 \mu \mathrm{g} / \mathrm{mL}$ ethidium bromide to validate the size of amplified fragments compared with the DNA size marker (ExcelBand ${ }^{\mathrm{TM}} 100 \mathrm{bp}+3 \mathrm{~K}$ DNA Ladder, Smobio, Taiwan).

\subsection{DNA Sequencing and Phylogenetic Analysis}

PCR products were directly sequenced by Microsynth (Balgach, Switzerland) using the primers F1 and R5. The resulting forward and reverse sequences of the 16S rRNA gene for each strain were assembled into a final consensus sequence using the CAP3 program [60]. The sequences were submitted to GenBank with the accession numbers of MW555322 and MW555323, with lengths of 1346 and $1393 \mathrm{bp}$, respectively. Then, the sequences were subjected to BLAST (Basic Local Alignment Search Tool) analysis at NCBI (https:/ /blast.ncbi.nlm.nih.gov / Blast.cgi), to compare with those from known Streptomyces strains. Then, closely related sequences were retrieved from GenBank and aligned using the ClustalW program included in the MEGA software version 7.0.26. Finally, a phylogenetic tree was constructed using the neighbor-joining statistical method [61] with 1000 bootstrap replicates to confirm inferred clades. The tree was rooted using the $16 \mathrm{~S}$ rRNA gene sequence from Mycobacterium helveticum (GenBank no. MT133249) as an out-group. Moreover, matrix similarity of the sequences (data not shown) was generated by the MatGat software, version 2.0 [62].

\subsection{Physiological Characterization}

For two active symbiont actinobacteria, evaluation of several enzymatic activities and tolerance to different concentrations of $\mathrm{NaCl}(0 \%, 1 \%, 2.5 \%, 5 \%, 10 \%)$ performed as described by Palaniyandi et al. [63]. Enzymatic bioassays included productions of gelatinase, catalase [64], citrate [65], and amylase [66]. The production of hydrogen cyanide $(\mathrm{HCN})$ and volatile organic compounds (VOC) $[67,68]$ were also assessed. The vulnerability of their activity to chloroform was performed as described by Jorjandi et al. [69].

\subsection{Greenhouse Evaluations}

\subsubsection{Preparation of Tomato Seed}

To conduct greenhouse trials, tomato seeds of Moneymaker cultivar were sterilized ( $2 \mathrm{~min} 2 \%$ sodium hypochlorite, $5 \mathrm{~min}$ successive rinses with sterilized distilled water). Next, the seeds were placed in capped Petri plates bearing Whatman filter paper No. 1 wetted with sterilized water, incubated at ambient temperature until seeds germinated, and then used for greenhouse experiments.

\subsubsection{Preparation of P. aphanidermatum Inocula}

To prepare P. aphanidermatum inocula, $100 \mathrm{~g}$ of millet seeds were added to $50 \mathrm{~mL}$ of distilled water in $500 \mathrm{~mL}$ Erlenmeyer flasks. The flasks autoclaved at $121^{\circ} \mathrm{C}$ for $40 \mathrm{~min}$ on three successive days to sterilize the millet seeds. Afterwards, the inoculation of seeds performed by adding eight plugs from a 3-day-old culture of P. aphanidermatum to each flask and incubated at $25^{\circ} \mathrm{C}\left( \pm 2{ }^{\circ} \mathrm{C}\right)$ for 4 days. In this period, to achieve uniform colonization, the flasks were shaken at least once a day [70]. 


\subsubsection{Soil Inoculation}

Two symbiont actinobacteria isolates ( $\mathrm{H} 2$ and $\mathrm{H} 3$ ) that showed the highest bioactivity against $P$. aphanidermatum in IPSB were cultured on CGA solid medium in $12 \mathrm{~cm}$ Petri plates and incubated at $28{ }^{\circ} \mathrm{C}$. A week later, spore suspension of actinobacteria was prepared aseptically by scarping off the surface of cultured plates in small aliquots of sterilized distilled water using a sterile scalpel. The concentration was adjusted at $10^{8} \mathrm{CFU} \mathrm{mL} \mathrm{m}^{-1}$ using a spectrophotometer (NanoDrop ${ }^{\mathrm{TM}}$, Thermo Scientific ${ }^{\mathrm{TM}}$ 840274200). Then, the suspension of each actinobacteria isolate was mixed with sterilized soil at the ratio of $10 \mathrm{~mL} \mathrm{~kg}^{-1}$ soil. Inoculated soil was incubated in sterile dark plastic bags at $28^{\circ} \mathrm{C}$ for three days and shaken twice daily to ensure thorough distribution and homogeneity of actinobacteria in the soil. For control treatment, only sterile distilled water was added to sterilized soil at a ratio of $10 \mathrm{~mL} \mathrm{~kg}^{-1}$ [32].

\subsubsection{Design of Sandwich Bed-Mixes}

The greenhouse trials were conducted from early June to early Sept 2020. Plastic pots with $20 \mathrm{~cm}$ diameter and $15 \mathrm{~cm}$ height were used in greenhouse experiments. We designed a Sandwich bed-mix used for plant beds. As schematically indicated in Figure 1, in this method, height wise, the pots were divided into 4 sections (A, B, C, and D, each section was about $3.5 \mathrm{~cm}$ ). From bottom-up, section D was filled with sterilized soil (no pathogen and no symbiont Streptomyces), section $C$ was filled with soil mixed with inoculum millet seeds $(0.5 \% w / w)$, section B was filled with soil inoculated with one of symbiont Streptomyces (H2 or H3), and section A, the top section, was filled with sterilized soil. Tomato seeds (cv. Moneymaker) were evenly sowed in section A. Statistically, greenhouse experiments were performed as a complete randomized design with seven treatments as follows: (1) negative control: all pot sections contained sterilized soil, $(2,3,4)$ symbiont Streptomyces isolates: layer B contained either one of $\mathrm{H} 2$ or $\mathrm{H} 3$ and layer C contained only sterilized soil, (5) positive control: layer $C$ contained inoculum millet seeds and layer $B$ contained only sterilized soil, $(6,7,8)$ symbiont Streptomyces isolates + pathogen: layer B contained either one of $\mathrm{H} 2$ or $\mathrm{H} 3$ and layer $\mathrm{C}$ contained inoculum millet seeds, (9) fungicide Metalaxyl + pathogen: layer $\mathrm{C}$ contained inoculum millet seeds, and layer $\mathrm{B}$ contained fungicide Metalaxyl (0.1\%) [32]. Each treatment was replicated thrice and mean values recorded for the triplicates. The pots kept in a greenhouse with a $16 / 8 \mathrm{~h}$ (light/dark) photoperiod and approximately $60 \%$ humidity (Table 1 ). No fertilizer was used throughout the experiment.

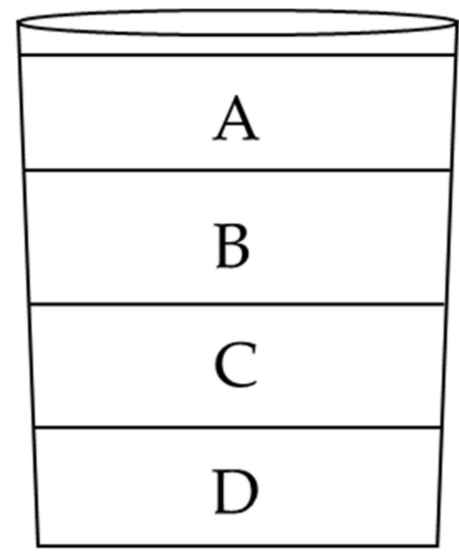

Figure 1. Schematic representation of Sandwich bed-mix used in greenhouse experiments. The pot bears four striated layers of sterilized soils which each receive specific treatment, e.g., in a challenge treatment having both the antagonist and the pathogen, the layers contain the following: (A) top sterilized soil, (B) sterilized soil plus the antagonist, (C) sterilized soil plus the pathogen, and (D) bottom sterilized soil. 
Table 1. Sandwich bed-mix treatments applied in greenhouse for plant beds to evaluate anti-Pythium aphanidermatum bioactivity of two Streptomyces symbionts on tomato seedlings (cv. Moneymaker).

\begin{tabular}{|c|c|c|}
\hline $\begin{array}{c}\text { Treatment } \\
\text { No. }\end{array}$ & Treatment & Treatment Description \\
\hline 1 & Positive control & $\begin{array}{l}\text { Millet seed Pythium aphanidermatum } \\
\text { inoculum }(0.5 \% w / w)\end{array}$ \\
\hline 2 & P. aphanidermatum $+\mathrm{H} 2$ & $\begin{array}{c}10 \mathrm{~mL} 10^{8} \mathrm{CFU} \text { spore suspension of } \mathrm{H} 2+ \\
\text { Millet seed Pythium aphanidermatum } \\
\text { inoculum }(0.5 \% w / w)\end{array}$ \\
\hline 3 & P. aphanidermatum $+\mathrm{H} 3$ & $\begin{array}{c}10 \mathrm{~mL} 10^{8} \mathrm{CFU} \text { spore suspension of } \mathrm{H} 3+ \\
\text { Millet seed Pythium aphanidermatum } \\
\text { inoculum }(0.5 \% w / w)\end{array}$ \\
\hline 4 & $\begin{array}{l}\text { P. aphanidermatum + Metalaxyl } \\
\text { (chemical fungicides) }\end{array}$ & $\begin{array}{l}\text { Millet seed Pythium aphanidermatum } \\
\text { inoculum }(0.5 \% w / w)+\text { Metalaxyl }(1 \%)\end{array}$ \\
\hline 5 & Symbiont Streptomyces isolate H2 & $\begin{array}{c}10 \mathrm{~mL} 10^{8} \mathrm{CFU} \text { spore suspension of } \mathrm{H} 2 \\
\mathrm{~kg}^{-1} \text { sterilized soil }\end{array}$ \\
\hline 6 & Symbiont Streptomyces isolate H3 & $\begin{array}{c}10 \mathrm{~mL} 10^{8} \mathrm{CFU} \text { spore suspension of } \mathrm{H} 3 \\
\mathrm{~kg}^{-1} \text { sterilized soil }\end{array}$ \\
\hline 7 & Negative control & $10 \mathrm{~mL}$ sterile water $\mathrm{kg}^{-1}$ sterilized soil \\
\hline
\end{tabular}

\subsubsection{Evaluation of Plants Responses}

After three months of greenhouse trials, the plant were uprooted by gentle washes with tap water. To assess the performance of the applied symbiont Streptomyces isolates, several parameters were measured and mean values of triplicates were calculated. Evaluated parameters are indicated as follows.

\section{Disease Incidence}

In the Sandwich bed-mix experiments, from the beginning and throughout the experiment, the number of germinated and perished seeds and seedlings was recorded. Compared to the number of plants in negative control, the percentage of disease incidences was calculated in triplicate treatments and used in statistical assessments.

The disease incidences was calculated using the following formula [71].

$$
\text { Disease incidence }(\%)=100 \times \sum_{i=0}^{n} X / \sum_{i=0}^{n} Y
$$

where $\mathrm{X}=$ number of dead tomato plants, $\mathrm{Y}=$ total number of tomato plants in each treatment, $\mathrm{n}=$ rating scale $(0-4)$.

Number of Leaves

At the end of the experiment, before uprooting, the number of leaves per plant was counted in triplicate, and the mean values were recorded.

Length of the Plants

Plant length including the length of stem from apex plus that of tap root to the tip. The plant length was monitored in triplicates in $\mathrm{cm}$ and mean values recorded.

\section{Plant Fresh Weights}

Plant weights comprised the total weight of plants, including both above and underground parts. After digging up the plants and gently washing the root, excess moisture was removed thoroughly by tissue papers. The total fresh weight of plants was recorded in triplicate treatments.

\section{Plant Dry Weights}

Following recording the total fresh weights of plants, specimens were placed in labeled pre-weighed paper bags and dried in $60{ }^{\circ} \mathrm{C}$ oven for $48 \mathrm{~h}$. After drying, bags were weighed 
accurately, and the subtraction of first and second weights was considered as plant dry weights for the triplicate treatments.

\subsection{Statistical Analyses}

Statistical analyses of mean values of greenhouse triplicate treatments were performed for analysis of variances (ANOVA) of completely randomized design experiment. The means were compared by Duncan's Multiple Range Test. SAS software v9.1 (SAS Institute Inc., Cary, NC 27513-2414, CA, USA) was applied to analyze data in the significant differences at $p \leq 0.05$.

\section{Results}

\subsection{Pathogenicity Test and Damping-Off Incidence}

In pathogenicity assessment experiment, infected seedling roots became necrotic, which was indicative of a pathological reaction. The pathogen-seedling interaction revealed that $P$. aphanidermatum was pathogenic on Lycopersicon esculentum cv. Moneymaker. The symptoms included firstly a discoloration of root and hypocotyl; then, the root and hypocotyl became water soaked and rotten (Figure S1, Supplementary Materials). In this bioassay evaluation, the disease incidence was observed in eight of nine tested seedlings.

\subsection{Isolated Soil Actinobacteria and In Vitro Screening}

By macroscopic and microscopic evaluations of culture plates, 160 actinobacteria pure isolates collected from soil cultures and stored at $4{ }^{\circ} \mathrm{C}$ as slants for further studies. The anti-Pythium activity of the 160 actinobacteria was isolated from soil conducted by dual culture bioassays and evaluated for inhibition bioactivity. From 160 actinobacteria isolates, 53 isolates exhibited moderate or strong inhibition activity against P. aphanidermatum. These active isolates selected as described by El-Tarabily et al. [57]. Both $\mathrm{H} 2$ and $\mathrm{H} 3$ isolates that showed a high antagonistic effect against $P$. aphanidermatum when tested on tomato seedlings (Figure 2).

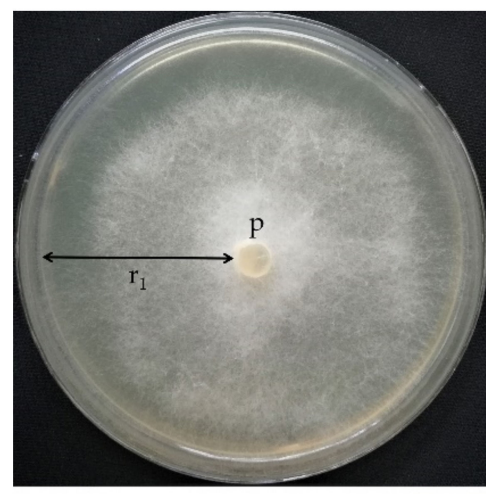

(a)

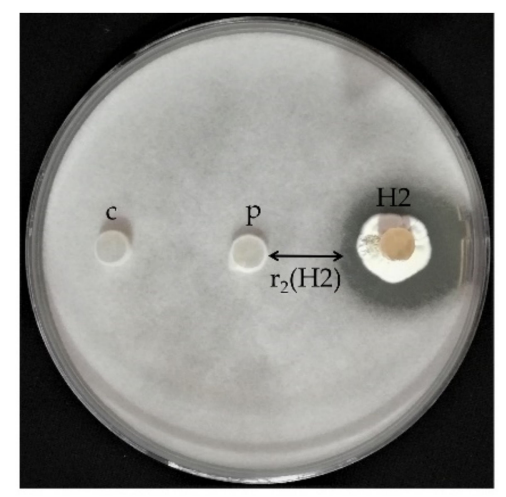

(b)

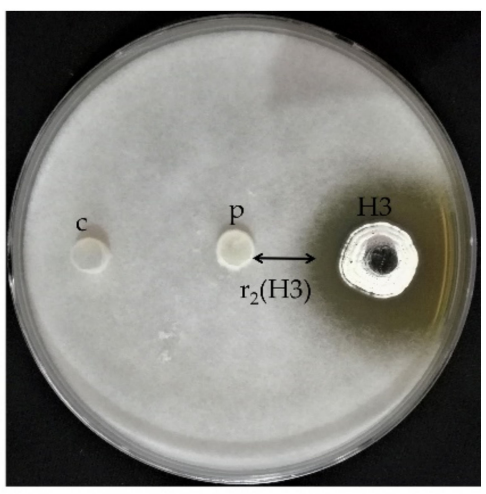

(c)

Figure 2. In vitro dual culture bioassay to select the bioactive actinomycetes isolates against Pythium aphanidermatum, quantitatively. (a) Arrow (r1) indicates the pathogen colony radius in control plate ( $7 \mathrm{~cm}$ diameter) in comparison with plate; (b) and (c) indicate the inhibitory effect on radii of $P$. aphanidermatum against actinomycetes isolates $\mathrm{H} 2$ and $\mathrm{H} 3$ (r2 $(\mathrm{H} 2)$ and $\mathrm{r} 2(\mathrm{H} 3)$ ). The blank agar plug (c) in each bioassay plate considered as control. Differential anti-Pythium activity was calculated from formula given in Section 2.4.

\subsection{In Vitro Petri Plate Seedling Bioassay}

The results of in vitro Petri plate seedling bioassay (IPSB) are presented in Figures 3 and 4. To shorten this section, the results in Figure 3 are indicted for the actinobacterium $\mathrm{H} 2$ isolate only. In less than 10 days, in Petri plates, the test well indicated the potential ability of active actinobacteria for root symbiosis and suppression of the P. aphanidermatum in tomato seedlings. Statistically, the protection (\%viability) of germinating tomato seeds 
coated with each of the actinobacteria was represented as follows: $9 \%$ for positive control (treated with P. aphanidermatum but no symbionts); $100 \%$ for negative control (untreated with neither pathogen nor symbiont); $73 \%$ and $64 \%$ for seeds coated with P. aphanidermatum and either of symbiont $\mathrm{H} 2$ or $\mathrm{H} 3$, respectively. As indicated in Figure 3, IPSB is relatively a fast bioassay and may be considered as a semi in vivo evaluation experiment. The symbiont actinobacteria exert their bioactivity via antibiosis and competitive exclusion [72]. In this bioassay, all 53 actinobacteria isolates, which were concluded as active in dual culture bioassays, were screened through IPSB among which the two isolates of H2 and H3 were selected for further evaluations including biochemical bioassays, molecular identifications, and in vivo greenhouse trials. According to El-Tarabily et al. [57], $\Delta$ r values included 2.0 for $\mathrm{H} 2$ and 2.1 for $\mathrm{H} 3$, which coincide with IPSB results.

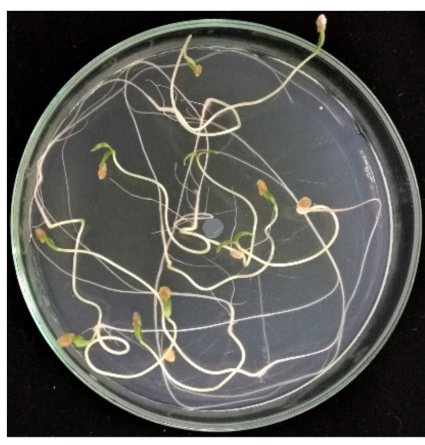

(a)

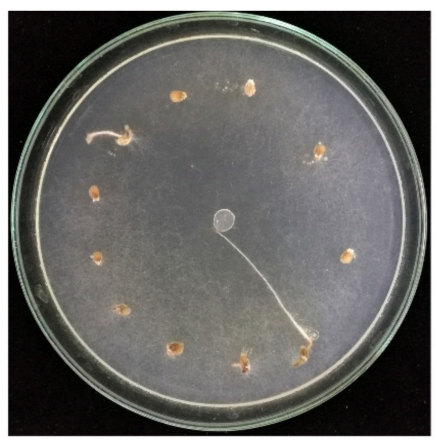

(b)

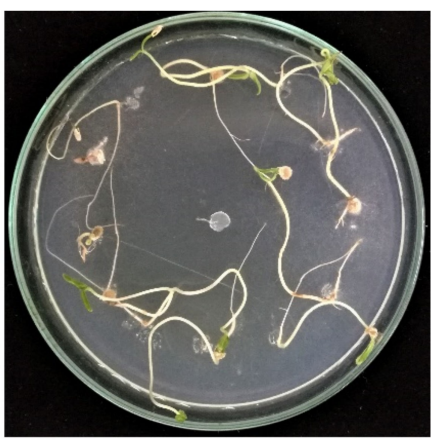

(c)

Figure 3. Evaluation of biocontrol activity of symbiont $\mathrm{H} 2$ actinobacterium isolate against Pythium aphanidermatum performed by tomato seed coating via in vitro Petri plate seedling bioassay (IPSB): (a) germinating untreated seeds (negative control); (b) germinating uncoated seeds placed from a $6 \mathrm{~mm}$ plug of P. aphanidermatum (positive control); (c) germinating coated seeds with spores of active actinobacteria isolates placed at equal distances of $2 \mathrm{~cm}$ vicinity of a $6 \mathrm{~mm}$ plug of $P$. aphanidermatum (challenge plate).

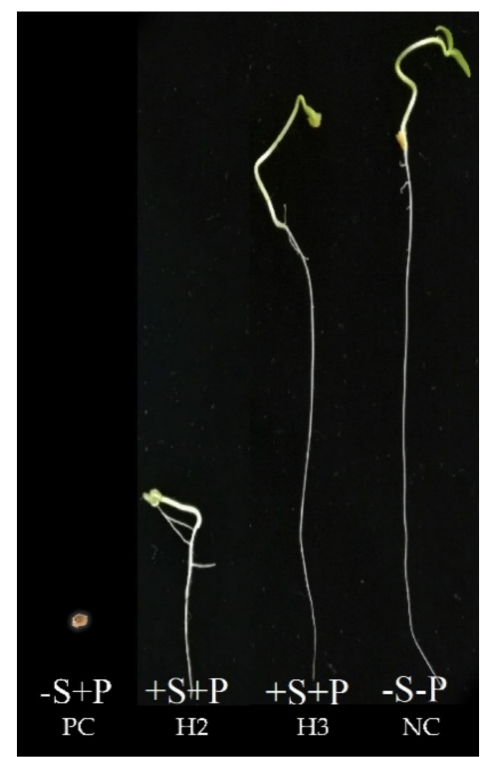

Figure 4. In vitro evaluation result of antagonistic activity of two symbiont actinobacteria isolates of $\mathrm{H} 2$ and $\mathrm{H} 3$ against pathogen Pythium aphanidermatum in tomato seedlings performed by tomato seed-coating via in vitro Petri plate seedling-bioassay (IPSB). Each picture is representative of its related treatment. $-\mathrm{S}+\mathrm{P}$ : no symbiont actinobacteria + pathogen, the positive control $(\mathrm{PC}) ;+\mathrm{S}+\mathrm{P}$ : symbiont actinobacteria ( $\mathrm{H} 2$ or $\mathrm{H} 3)+$ pathogen and $-\mathrm{S}-\mathrm{P}$ : no symbiont actinobacteria + no pathogen, the negative control (NC). 


\subsection{In Vitro Root Colonization Bioassay}

The formation and growth of colonies on CGA medium indicated that both actinobacteria isolates, $\mathrm{H} 2$ and $\mathrm{H} 3$, colonized the tomato seedling roots (Figure 5). Apparently, spores of seed-coated actinobacteria germinate and utilize exudates of spermosphere and subsequently propagate on exudates of root surface; hence, they would act as symbionts in a symbiotic relationship where both plant and participating actinobacteria benefit from each other, which is a relationship referred to as mutualism. This process often leads to fully colonized root system. Root colonization is an advantage of such symbionts in their biocontrol behavior [73].

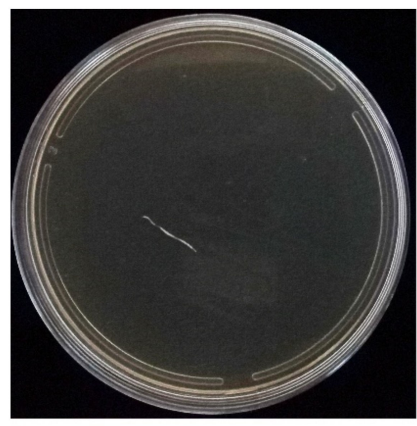

(a)

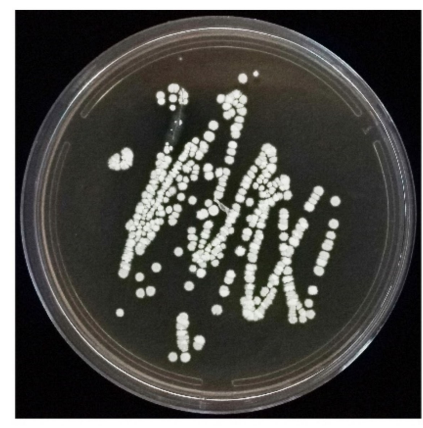

(b)

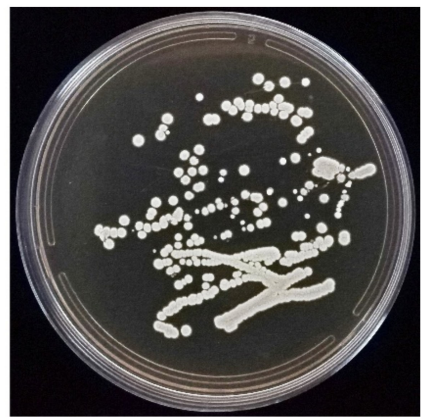

(c)

Figure 5. Result of root colonization of tomato seedling roots by two actinobacteria symbionts of $\mathrm{H} 2$ and $\mathrm{H} 3$. The growth of symbionts colonies on CGA medium indicated that both actinobacteria isolates, $\mathrm{H} 2$ and $\mathrm{H} 3$, colonized the tomato seedling roots. (a) Control; includes seeds treated only with sterilized distilled water (no symbiont isolates used); (b,c) colonies formed from aseptic smearing of cut 4-6 mm of elongation zones of roots of each treatment on CGA medium.

\subsection{PCR Amplification of $16 S$ rRNA Gene and Phylogeny Analysis}

PCR with the 16Sr RNA gene universal primers F1 and R5 amplified a fragment with the expected size of $1490 \mathrm{bp}$ from the Streptomyces strains H2 and H3 (Figure 6). Based on the $16 \mathrm{~S}$ rRNA gene sequences phylogenetic tree (Figure 7) and matrix similarity, the $\mathrm{H} 2$ strain was clustered together with the species S. badius, S. caviscabies, S. globisporus, S. parous, S. sindenensis, and S. griseoplanus, and the strain $\mathrm{H} 3$ was clustered with the species S. flavogriseus, and S. pratensis with $99.9 \%$ similarity.

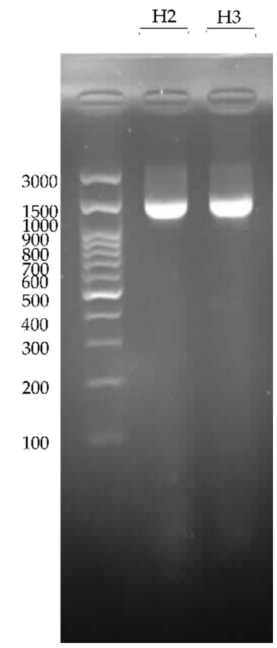

Figure 6. Agarose gel electrophoresis (1\%) image of PCR amplification of the 16S rRNA gene of two actinomycetes isolates. M: molecular marker (ExcelBand ${ }^{\mathrm{TM}} 100 \mathrm{bp}+3 \mathrm{~K}$ DNA Ladder, Smobio, Taiwan); lines $\mathrm{H} 2$ and $\mathrm{H} 3$ represent PCR product of the related actinomycetes. 


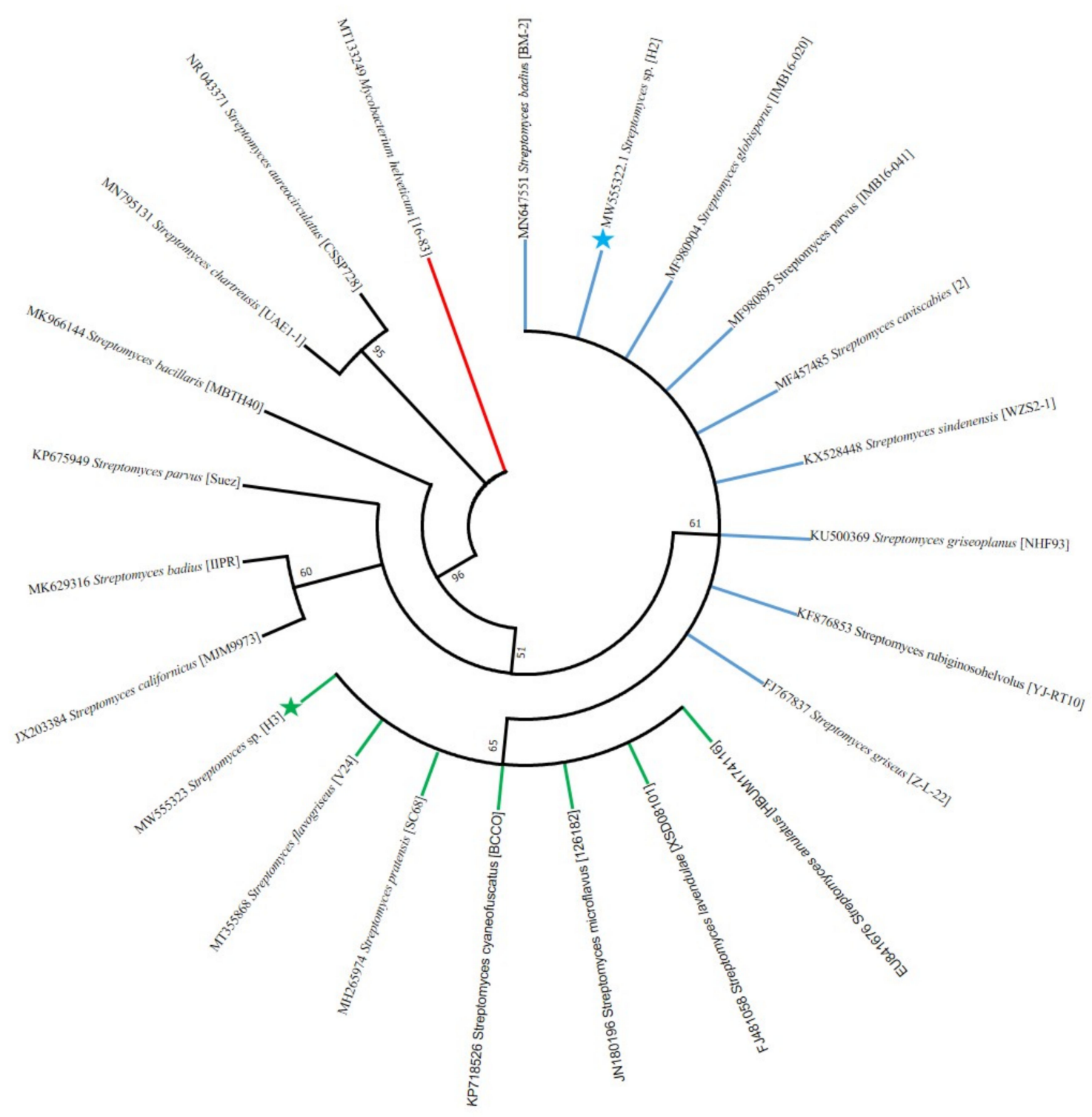

Figure 7. Phylogenetic relations of the Streptomyces strains $\mathrm{H} 2$ and $\mathrm{H} 3$ isolates with 20 known Streptomyces strains, based on 16S rRNA gene sequences obtained from GenBank. The tree was constructed using the neighbor-joining method in the MEGA program, version 7.0. Bootstrap values more than 50\% from 1000 resampling are shown at the nodes. The $16 \mathrm{~S}$ rRNA gene sequence from Mycobacterium helveticum 16-83 (accession no. MT133249) was used as the out-group.

\subsection{Physiological Characterization}

The results of physiological characterization of two active symbiont Streptomyces strains are indicated in Table 2. Results revealed that both isolates produced gelatinase, catalase, and amylase and could utilize the citrate as a carbon source. Chloroform bioassay showed that bioactive compounds of $\mathrm{H} 2$ strain are sensitive to chloroform and became inactive, while those of the $\mathrm{H} 3$ strain were resistant to chloroform. Evaluation of the production of volatile organic compounds and $\mathrm{HCN}$ revealed that neither strain was able to produce either compound. The maximum tolerable concentrations of $\mathrm{NaCl}$ for $\mathrm{H} 2$ and H3 strains were $5 \%$ for each. 
Table 2. Results of physiological characterization of two active symbiont Streptomyces strains of H2 and $\mathrm{H} 3$.

\begin{tabular}{|c|c|c|}
\hline Bioassay & H2 & H3 \\
\hline Catalase production & + & + \\
\hline Gelatinase production & + & + \\
\hline Amylase production & + & + \\
\hline Citrate utilization & + & + \\
\hline $\mathrm{HCN}^{1}$ production & - & - \\
\hline $\mathrm{VOC}^{2}$ production & - & - \\
\hline Deactivated by chloroform & + & - \\
\hline
\end{tabular}

${ }^{1} \mathrm{HCN}$ : Hydrogen Cyanide, ${ }^{2}$ VOC: Volatile Organic Compound.

\subsection{Greenhouse Evaluations}

Greenhouse results indicated that the two symbiont Streptomyces strains acted as valuable means to subside the disease onset and helped enhance the plants' performance (Figure 8). Results of evaluated criteria are described as follows.

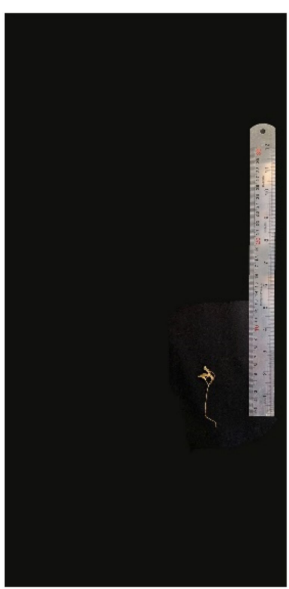

(a)

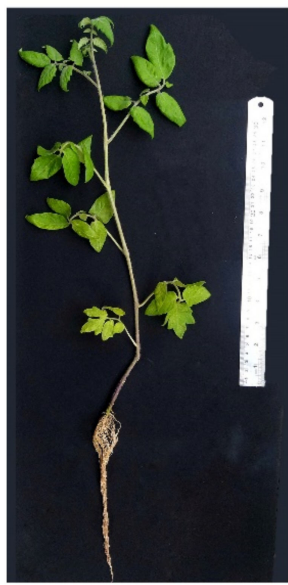

(e)

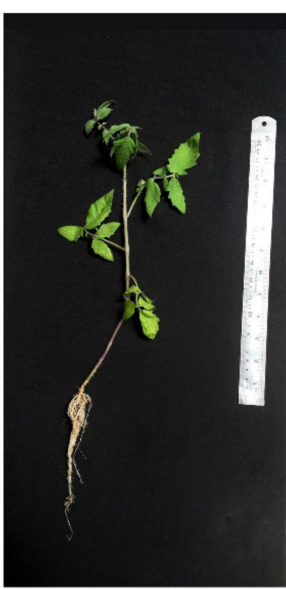

(b)

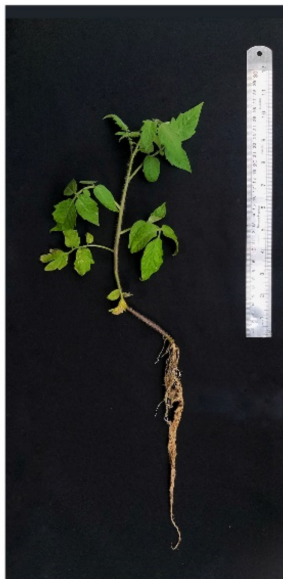

(f)

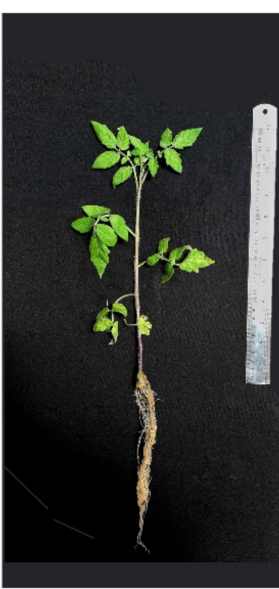

(c)

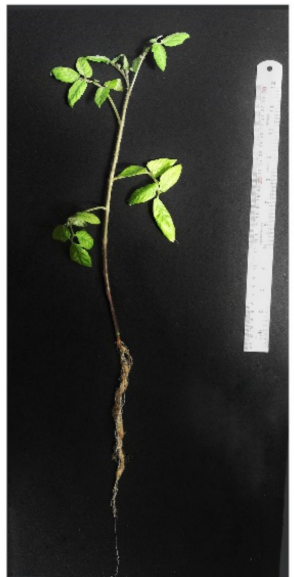

(g)

Figure 8. Pictorial results of greenhouse statistical evaluations of interaction between two Streptomyces root symbionts, $\mathrm{H} 2$ and $\mathrm{H} 3$ strains, and the causal agent of damping-off disease, Pythium aphanidermatum, on criterion of plant length in tomato seedlings. Each picture is representative of its related treatment: (a) tomato seedling treated with P. aphanidermatum (positive control); (b) seedlings treated neither with pathogen nor symbiont (negative control); (c and d) seedlings treated with either symbiont Streptomyces strains of $\mathrm{H} 2$ or H3; (e,f) seedlings treated with pathogen and either of symbiont isolates $\mathrm{H} 2$ or $\mathrm{H} 3$ respectively; (g) seedling treated with Metalaxyl (chemical fungicide). 


\subsubsection{Biocontrol Efficacy of Symbiont Streptomyces Strains}

The efficacy of symbiont Streptomyces strains evaluated through several parameters are described in following subsections.

\section{Disease Incidence}

As indicated in Table 3, the highest disease incidence (47\%) belongs to positive control (PC) and the lesser incidences belong to negative control (NC), two symbiont Streptomyces strains, and Metalaxyl (Chemical fungicide) treatments. In treatments that received the pathogen and each of two symbiont Streptomyces strains, disease incidences (DI) were 31.3\% and $21 \%$ for symbiont Streptomyces strains $\mathrm{H} 2$ and H3, respectively. For a better insight into the efficacies of two antagonists, disease incidence adjusted to positive control (\%), equalizing disease incidence of positive control to $100 \%$ and adjusting the values of other treatments to it, respectively. Accordingly, reduced disease incidence (compared to positive control) was obtained by subtracting disease incidence from $100 \%$. Indeed, the values of reduced disease incidence (\%) are indicative of quantitative representation of biocontrol activity of Streptomyces strains of $\mathrm{H} 2$ and $\mathrm{H} 3$.

\section{Number of Leaves}

However, as indicated in Table 3, there existed a statistical difference between these treatments and positive control, while there was no statistical difference between negative control, Metalaxyl, and symbiont Streptomyces strains at $p \leq 0.05$.

\section{Plants Length}

As indicated in Table 3, there existed statistical differences between the plant lengths of the positive control and all other treatments; however, there were no statistical differences among the negative control, $\mathrm{H} 2+$ pathogen, and $\mathrm{H} 3+$ pathogen at $p \leq 0.05$.

\section{Fresh and Dry Plant Weights}

Compared to positive and negative controls, analysis of fresh and dry plant weights showed that Streptomyces strain $\mathrm{H} 2$ promoted both fresh and dry plant weights while strain H3 enhanced only plant dry weight (Table 3). Considering this criterion, Streptomyces strain $\mathrm{H} 2$ may be acting as PGPRs.

Table 3. Results of in vivo greenhouse evaluations of two Streptomyces root symbionts, $\mathrm{H} 2$ and H3 strains, against Pythium aphanidermatum, which is the causal agent of damping-off disease in tomato. Evaluated criteria included mean values of triplicates in seven treatments. Recorded criteria in treatments comprised: percentage disease incidence, number of leaves, plant length, fresh and dry stem weights.

\begin{tabular}{|c|c|c|c|c|c|c|c|c|}
\hline $\begin{array}{c}\text { Treatment } \\
\text { No. }\end{array}$ & Treatment & $\% \mathrm{DI}^{1}$ & $\% \mathrm{APC}^{2}$ & $\%$ RDI $^{3}$ & $\mathrm{MNL}^{4}$ & $\begin{array}{c}\mathrm{MPL}^{5} \\
(\mathrm{~cm})\end{array}$ & $\begin{array}{c}\text { MFSW }^{6} \\
\text { (g) }\end{array}$ & $\begin{array}{c}\text { MDSW }^{7} \\
\text { (g) }\end{array}$ \\
\hline 1 & P. aphanidermatum ${ }^{8}$ & $47^{\mathrm{a}}$ & $100 \%$ & $0 \%$ & $1.9^{\mathrm{c}}$ & $8^{c}$ & $0.8^{c}$ & $0.1^{\mathrm{e}}$ \\
\hline 2 & P. aphanidermatum $+\mathrm{H} 2$ & $31.3^{\mathrm{ab}}$ & $66.6 \%$ & $33.4 \%$ & $4.4^{\mathrm{b}}$ & $42.3^{\mathrm{ab}}$ & $3.0^{\mathrm{b}}$ & $0.3^{\mathrm{cd}}$ \\
\hline 3 & P. aphanidermatum $+\mathrm{H} 3$ & $21^{b}$ & $44.7 \%$ & $55.3 \%$ & $4.9^{\mathrm{ab}}$ & $43.3^{a b}$ & $2.6^{b}$ & $0.2^{\mathrm{de}}$ \\
\hline 4 & $\begin{array}{c}\text { P. aphanidermatum }+ \\
\text { Metalaxyl }\end{array}$ & $0^{b}$ & $0 \%$ & $100 \%$ & $5^{a b}$ & $40.4^{\mathrm{ab}}$ & $2.6^{b}$ & $0.3^{\mathrm{cd}}$ \\
\hline 5 & Streptomyces strains $\mathrm{H} 2$ & $0^{b}$ & $0 \%$ & $100 \%$ & $6.8^{\mathrm{a}}$ & $43.8^{\mathrm{ab}}$ & $5.6^{\mathrm{a}}$ & $0.6^{\mathrm{a}}$ \\
\hline 6 & Streptomyces strains $\mathrm{H} 3$ & $0^{b}$ & $0 \%$ & $100 \%$ & $6^{\mathrm{ab}}$ & $46^{\mathrm{a}}$ & $3.9^{b}$ & $0.5^{\mathrm{a}}$ \\
\hline 7 & $\mathrm{NC}^{9}$ & $0^{b}$ & $0 \%$ & $100 \%$ & $5.5^{\mathrm{ab}}$ & $40^{\mathrm{ab}}$ & $3.4^{b}$ & $0.4^{b c}$ \\
\hline
\end{tabular}

${ }^{1}$ Disease incidence (DI, \%); ${ }^{2}$ disease incidence adjusted to positive control (APC, $\left.\%\right) ;{ }^{3}$ reduced disease incidence compared to positive control (RDI, \%); ${ }^{4}$ mean of number of leaves (MNL); ${ }^{5}$ mean of plant length (MPL); ${ }^{6}$ mean of fresh stem weights (MFSW); ${ }^{7}$ mean of dry stem weights (MDSW); ${ }^{8}$ positive controls (P. aphanidermatum); ${ }^{9}$ negative controls (no pathogen, no symbiont). For a given parameter, different letters indicate significant differences between the different treatments (Duncan's test; $p<0.05$ ). 


\section{Discussion}

Damping-off and root diseases of vegetable crops can be controlled using chemical treatments. However, these chemicals negatively impact the environment and humans. Therefore, application of environmentally safe pesticides is a worldwide need in sustainable agricultural pest managements.

Pythium aphanidermatum is a soil-borne phytopathogen and a major causal agent of damping-off disease in many plant species. The pathogen severely damages tomato plants especially in nurseries and greenhouses all over the world [20]. In the present research, 160 pure culture actinobacteria isolated from rhizospheric soil of tomato healthy-appearing fields were screened, in vitro and in vivo, for their anti-Pythium activity. This step provided two Streptomyces root symbionts, $\mathrm{H} 2$ and $\mathrm{H} 3$, both with potent biocontrol activities to control tomato damping off disease, which were further characterized in detail at both physiological and molecular levels.

Streptomyces spp. are not only considered for the production of antibiotics but also as a potential biological control of plant pathogenic fungi and bacteria. For instance, Streptomyces sp. strain CACIS-1.5CA has been shown to have high bioactivity against several plant pathogenic fungi by inhibition of their spore germination [74]. The antifungal and antibacterial activity of Streptomyces sp. strain FJAT-31547 controlled several species of phytopathogenic fungi and bacteria in tomato [71]. Similarly, Streptomyces spp. isolate KUBPMB1.1 was efficient to control the P. aphanidermatum [34]. The main biocontrol mechanisms of Streptomyces species consist of antibiosis by the production of antibiotics [75] and hydrolyzing enzymes. Their activity against phytopathogens consist of producing extra cellular hydrolyzing and degrading enzymes such as cellulases, amylases, chitinases, lipases, etc. [76]. Actinobacteria form an important part of the microbial communities in the soil but also in the rhizosphere and endospheric zones of plant roots [77]. To elucidate the root colonization affinity of Streptomyces spp., we developed an "in vitro Petri plate seedling-bioassay" (IPSB), which is relatively a fast bioassay and may be considered as a semi in vivo evaluation bioassay. The IPSB well indicated the potential ability of active actinobacteria for root symbiosis. By implementing this bioassay, we screened 53 actinobacteria isolates, which were demonstrated to be active in dual culture bioassays.

The bioassay test indicated a significant effect of two symbiont Streptomyces strains, $\mathrm{H} 2$ and $\mathrm{H} 3$, on the survival of tomato seedlings inoculated by P. aphanidermatum. Both $\mathrm{H} 2$ and $\mathrm{H} 3$, which revealed their biocontrol potencies, were used to compose main bulk of this paper. Streptomyces strain H3 retained its antagonistic activity after exposure to chloroform, a reagent that denatures enzymes, which indicates the involvement of some non-proteinaceous anti-Pythium secondary metabolite(s). These results are consistent with other previous results showing that actinobacteria in general, and Streptomyces sp. in particular, are of great importance in the field of biotechnology, as producers of a wild range of bioactive secondary metabolites of which many with antibiotic activities that are used in medicine and agriculture [78]. Biochemical bioassay results showed that the two Streptomyces strains of $\mathrm{H} 2$ and $\mathrm{H} 3$ are tolerant to relatively high concentrations of $\mathrm{NaCl}$. Such criteria imply that these strains may be appropriate candidates for biocontrol approaches in saline soils. The biochemical bioassays also showed that two Streptomyces strains are able to produce catalase, amylase, and gelatinase. The utilization of citrate showed that these strains can use citrate as a carbon source.

The $16 \mathrm{~S}$ rRNA-phylogeny confirmed a close relationship of the $\mathrm{H} 2$ to the species $S$. badius, S. caviscabies, S. globisporus, S. parvus, S. sindenensis, and S. griseoplanus, and H3 isolate to $S$. flavogriseus, and S. pratensis among 675 validly published Streptomyces species (https: //lpsn.dsmz.de/genus/streptomyces). The 16S rRNA gene sequencing is not always able to differentiate Streptomyces species [79], and it is more proper to discriminate moderately or distantly related species. Hence, to clarify the phylogeny of closely related species in the $16 \mathrm{~S}$ rRNA gene clades, a multilocus sequence analysis scheme using the other housekeeping genes, atpD, gyr $\mathrm{B}, r e c A, r p o \mathrm{~B}$, and $\operatorname{trp} B$ is suggested [80]. 
Actinomycetes have been reported as efficient biocontrol agents of different soil pathogens through the production of a range of antibiotics with both antibacterial and antifungal action [80] against Fusarium spp. [81], Phytophthora spp. [82], Rhizoctonia spp. [83], Verticillium spp. [84], and Pythium spp. [85]. The efficacy of bioactivity of $\mathrm{H} 2$ and $\mathrm{H} 3$ isolates was evidenced in greenhouse trials; however, statistical evaluations showed that similar to the fungicide Metalaxyl, both Streptomyces root symbionts significantly suppress the damping-off disease caused by P. aphanidermatum. These results are in accordance with reports indicating the antifungal activity of various strains of Streptomyces [80]. Furthermore, Streptomyces strains were able to reduce the in vitro growth of Rhizoctonia and significantly reduce the disease index triggered by this agent when tomato seeds were inoculated with these strains [86]. In addition, S. anulatus S37 isolated from the rhizosphere of healthy wild Vitis vinifera have been shown as a plant growth-promoting bacteria that enhances the disease resistance toward several pathogens including B. cinerea [87]. Hence, when safety procedures passed, these two Streptomyces strains can be considered in IPM as appropriate biofungicides. Interestingly, in the criteria of plant weight, the two strains behaved as PGPRs. The increase in plant growth due to antagonist application may be due to the plant growth-promoting characteristics of biocontrol agents [78,88]. Indeed, the greenhouse results indicate that these two root symbionts can be promising candidates to invest on as novel biological control agents in line with the goals of sustainable agriculture. Notably, none of them showed adverse allelopathic effects on plant growth; hence, they are well compatible root symbionts in tomato plant.

In this regard, the study of the effects of both bioactive strains on the rhizosphere microflora (beneficial and/or pathogenic microorganisms) would be useful in future studies, and it would be a great step forward along with goals of sustainable agriculture.

As our results indicate, root symbionts can be considered as promising root-colonizing candidates in integrated management of the damping-off diseases of vegetables in the future. To make such desire come through, further investigations should improve our knowledge of their physiology and environmental accomplishments, including their beneficial or adverse effects on biological stability of the soil; their interaction with other plant root pathogens; their interaction with root mycorrhizae, their interaction with roots of weedy plants, their interaction with other biocontrol agents in soil, their interaction with phyllosphere pathogens, their interaction with endophyte microorganisms, their residual adverse effects on humans through edible plant roots as carrots and even the probable consequences of their genetic transformation such as transduction or conjugation with other prokaryotes, their behavior in other new habitats as forests, rivers, oceans, etc.

This investigation indicated that there were no significant differences between disease control by the chemical fungicide (Metalxyl ${ }^{\circledR}$ ) and either of the two Streptomyces root symbionts, $\mathrm{H} 2$ and $\mathrm{H} 3$. This perception indicates that there is promise in considering them as candidates for seed treatment and/or soil applications in integrated management of tomato damping-off disease in the future. The current results indicate that these two symbionts are desirable candidates for future investiture in projects with organic agricultural goals.

This is the first report of biocontrol of damping-off in tomato plants caused by $P$. aphanidermatum managed by applying Streptomyces in Iran and the second report of employment of Streptomyces spp. for biological control of damping-off in tomato caused by $P$. aphanidermatum [34].

Certainly, a wider evaluation of antimicrobial activities of the two bioactive symbionts against other tomato phytopathogens would further add to the knowledge on the bioactivity of these bioactive Streptomyces. Furthermore, the assessment of antifungal activity of the two bioactive agents against other causal agents of tomato root disease agents such as Fusarium spp., Verticillium dahlia, Rhizoctonia solani, and Phytophthora spp. [3,89] can improve our knowledge on their future applications. 


\section{Conclusions}

Streptomyces spp. are clearly an important part of the soil and/or root microbiome and actively contribute to the control of plant soil pathogens. However, very few products based on Streptomyces strains or their bioactive molecules are available on the market. This investigation revealed that (a) the two symbionts Streptomyces strain $\mathrm{H} 2$ and $\mathrm{H} 3$ are appropriate candidates for future investigations as bio-control agents for root fungal pathogens of tomato plants, (b) they behave as plant growth-promoting rhizobacteria able to increase fresh and dry weight of tomato plants; and (c) their biosafety and environmental suitability is yet to be meticulously revealed; however, their immediate field application is not recommended yet.

Supplementary Materials: The following are available online at https://www.mdpi.com/article/ 10.3390/agronomy11050846/s1, Figure S1: Assessment of Pythium aphanidermatumpathogenicity on tomato seedlings (Lycopersicon esculentum $\mathrm{cv}$. Moneymaker) in vitro. Healthy non-inoculated seedling (left) and discoloredand P. aphanidermatum-killed seedling (right).

Author Contributions: M.H.; Writing, Methodology, G.H.S.B.; Project Administration, Supervision, Writing, Methodology; A.H.; Supervision of Molecular Identification Validation and Writing; R.A.; Supervision of Statistical Analysis; E.A.B.; Review and Editing; I.S.; Review and Editing. All authors have read and agreed to the published version of the manuscript.

Funding: This study was financially supported by grant No. 99/10910 of the Biotechnology Development Council of the Islamic Republic of Iran. Supports of Research Office of Kerman University of Shahid Bahonar and Research and Technology Institute of Plant Production (RTIPP) are highly appreciated.

Acknowledgments: The spirit of this research is dedicated to the souls of Alireza Afzalipour and Fakhereh Saba, the Founders of Universities in Kerman, Iran.

Conflicts of Interest: The authors declare no conflict of interest.

\section{References}

1. FAO; IFAD; UNICEF; WFP; WHO. The State of Food Security and Nutrition in the World 2020. Transforming Food Systems for Affordable Healthy Diets; FAO: Rome, Italy, 2020. [CrossRef]

2. Hartley, C.; Pierce, R. The Control of Damping-Off of Coniferous Seedlings; United States Department of Agriculture: Washington, DC, USA, 1917; Volume 453.

3. Lamichhane, J.; Dürr, C.; Schwanck, A.; Robin, M.; Sarthou, J.; Cellier, V.; Messéan, A.; Aubertot, J. Integrated management of damping-off diseases. A review. Agron. Sustain. Dev. 2017, 37, 10. [CrossRef]

4. Al-Sheikh, H. Two pathogenic species of Pythium: P. aphanidermatum and P. diclinum from a wheat field. Saudi J. Biol. Sci. 2010, 17, 347-352. [CrossRef] [PubMed]

5. Hendrix, F.; Campbell, W. Pythiums as plant pathogens. Annu. Rev. Phytopathol. 1973, 11, 77-98. [CrossRef]

6. Daughtrey, M.L.; Wick, R.L.; Peterson, J.L. Compendium of Flowering Potted Plant Diseases; APS Press: St. Paul, MN, USA, 1995.

7. Parveen, T.; Sharma, K. Pythium diseases, control and management strategies: A review. Int. J Plant Anim. Environ. Sci. 2015, 5, 244-257.

8. Van der Plaats-Niterink, A.J. Monograph of the genus Pythium. In Studies in Mycology; Centraalbureau voor Schimmelcultures (Baarn): Baarn, The Netherlands, 1981; Volume 21, 244p.

9. Abdelzaher, H.M. Occurrence of damping-off of wheat caused by Pythium diclinum tokunaga in El-Minia, Egypt and its possible control by Gliocladium roseum and Trichoderma harzianum. Arch. Phytopathol. Plant Prot. 2004, 37, 147-159. [CrossRef]

10. Elshahawy, I.; Abouelnasr, H.M.; Lashin, S.M.; Darwesh, O.M. First report of Pythium aphanidermatum infecting tomato in Egypt and its control using biogenic silver nanoparticles. J. Plant Prot. Res. 2018, 58, 137-151. [CrossRef]

11. Jones, S.; Donaldson, S.; Deacon, J. Behaviour of zoospores and zoospore cysts in relation to root infection by Pythium aphanidermatum. New Phytol. 1991, 117, 289-301. [CrossRef]

12. Moorman, G.; Kang, S.; Geiser, D.M.; Kim, S. Identification and characterization of Pythium species associated with greenhouse floral crops in Pennsylvania. Plant Dis. 2002, 86, 1227-1231. [CrossRef]

13. Stephens, C.; Herr, L.; Schmitthenner, A.; Powell, C. Sources of Rhizoctonia solani and Pythium spp. in the bedding plant greenhouse. Plant Dis. 1983, 67, 272-275. [CrossRef]

14. Lookabaugh, E.C.; Kerns, J.P.; Cubeta, M.A.; Shew, B.B. Fitness Attributes of Pythium aphanidermatum with Dual Resistance to Mefenoxam and Fenamidone. Plant Dis. 2018, 102, 1938-1943. [CrossRef]

15. Pérez, W.; Lara, J; Forbes, G.A. Resistance to metalaxyl-M and cymoxanil in a dominant clonal lineage of Phytophthora infestans in Huánuco, Peru, an area of continuous potato production. Eur. J. Plant Pathol. 2009, 125, 87-95. [CrossRef] 
16. Utkhede, R.; Gupta, V. In vitro selection of strains of Phytophthora cactorum resistant to metalaxyl. J. Phytopathol. 1988, 122, 35-44. [CrossRef]

17. Sabarwal, A.; Kumar, K.; Singh, R.P. Hazardous effects of chemical pesticides on human health-Cancer and other associated disorders. Environ. Toxicol. Pharmacol. 2018, 63, 103-114. [CrossRef] [PubMed]

18. Wightwick, A.; Walters, R.; Allinson, G.; Reichman, S.; Menzies, N. Environmental Risks of Fungicides Used in Horticultural Production Systems; Carisse, O., Ed.; InTech: Rijeka, Croatia, 2010; Volume 1, pp. 273-304.

19. Sood, M.; Kapoor, D.; Kumar, V.; Sheteiwy, M.S.; Ramakrishnan, M.; Landi, M.; Araniti, F.; Sharma, A. Trichoderma: The "Secrets" of a Multitalented Biocontrol Agent. Plants 2020, 9, 762. [CrossRef] [PubMed]

20. Kipngeno, P.; Losenge, T.; Maina, N.; Kahangi, E.; Juma, P. Efficacy of Bacillus subtilis and Trichoderma asperellum against Pythium aphanidermatum in tomatoes. Biol. Control 2015, 90, 92-95. [CrossRef]

21. Sajeena, A.; Nair, D.S.; Sreepavan, K. Non-pathogenic Fusarium oxysporum as a biocontrol agent. Indian Phytopathol. 2020, 73, 177-183. [CrossRef]

22. Kobayashi, D.Y.; Guglielmoni, M.; Clarke, B.B. Isolation of the chitinolytic bacteria Xanthomonas maltophilia and Serratia marcescens as biological control agents for summer patch disease of turfgrass. Soil Biol. Biochem. 1995, 27, 1479-1487. [CrossRef]

23. Ben Khedher, S.; Boukedi, H.; Laarif, A.; Tounsi, S. Biosurfactant produced by Bacillus subtilis V26: A potential biological control approach for sustainable agriculture development. Org. Agric. 2020, 10, 117-124. [CrossRef]

24. Wang, S.; Sun, L.; Zhang, W.; Chi, F.; Hao, X.; Bian, J.; Li, Y. Bacillus velezensis BM21, a potential and efficient biocontrol agent in control of corn stalk rot caused by Fusarium graminearum. Egypt. J. Biol. Pest Control 2020, 30, 9. [CrossRef]

25. Mohammed, A.F.; Oloyede, A.R.; Odeseye, A.O. Biological control of bacterial wilt of tomato caused by Ralstonia solanacearum using Pseudomonas species isolated from the rhizosphere of tomato plants. Arch. Phytopathol. Plant Prot. 2020, 53, 1-16. [CrossRef]

26. El-Tarabily, K.A.; Nassar, A.H.; Hardy, G.E.; Sivasithamparam, K. Plant growth promotion and biological control of Pythium aphanidermatum, a pathogen of cucumber, by endophytic actinomycetes. J. Appl. Microbiol. 2009, 106, 13-26. [CrossRef]

27. Kaur, T.; Rani, R.; Manhas, R.K. Biocontrol and plant growth promoting potential of phylogenetically new Streptomyces sp. MR14 of rhizospheric origin. AMB Express 2019, 9, 125. [CrossRef]

28. Newitt, J.T.; Prudence, S.M.M.; Hutchings, M.I.; Worsley, S.F. Biocontrol of Cereal Crop Diseases Using Streptomycetes. Pathogens 2019, 8, 78. [CrossRef] [PubMed]

29. Olanrewaju, O.S.; Babalola, O.O. Streptomyces: Implications and interactions in plant growth promotion. Appl. Microbiol. Biotechnol. 2019, 103, 1179-1188. [CrossRef]

30. Elshahawy, I.E.; El-Mohamedy, R.S. Biological control of Pythium damping-off and root-rot diseases of tomato using Trichoderma isolates employed alone or in combination. J. Plant Pathol. 2019, 101, 597-608. [CrossRef]

31. Halo, B.A.; Al-Yahyai, R.A.; Al-Sadi, A.M. Aspergillus terreus Inhibits Growth and Induces Morphological Abnormalities in Pythium aphanidermatum and Suppresses Pythium-Induced Damping-Off of Cucumber. Front. Microbiol. 2018, 9, 95. [CrossRef] [PubMed]

32. Al-Hussini, H.S.; Al-Rawahi, A.Y.; Al-Marhoon, A.A.; Al-Abri, S.A.; Al-Mahmooli, I.H.; Al-Sadi, A.M.; Velazhahan, R. Biological control of damping-off of tomato caused by Pythium aphanidermatum by using native antagonistic rhizobacteria isolated from Omani soil. J. Plant Pathol. 2019, 101, 315-322. [CrossRef]

33. Halo, B.A.; Al-Yahyai, R.A.; Maharachchikumbura, S.S.N.; Al-Sadi, A.M. Talaromyces variabilis interferes with Pythium aphanidermatum growth and suppresses Pythium-induced damping-off of cucumbers and tomatoes. Sci. Rep. 2019, 9, 11255. [CrossRef] [PubMed]

34. Beena Kanimozhi, R.; Paul Raj, R. Biological Control of Pythium Damping-off in Seedlings with Streptomyces sp. Int. J. Recent Technol. Eng. 2019, 8, 8035-8039. [CrossRef]

35. Kloepper, J.; Schroth, M. Plant growth-promoting rhizobacteria and plant growth under gnotobiotic conditions. Phytopathology 1981, 71, 642-644. [CrossRef]

36. Mohammadipanah, F.; Dehhaghi, M. Classification and taxonomy of Actinobacteria. In Biology and Biotechnology of Actinobacteria; Springer: Berlin/Heidelberg, Germany, 2017; pp. 51-77.

37. Kämpfer, P. The family Streptomycetaceae, part I: Taxonomy. In The Prokaryotes, 3rd ed.; Springer: New York, NY, USA, 2006; pp. 538-604.

38. Manteca, Á.; Yagüe, P. Streptomyces as a source of antimicrobials: Novel approaches to activate cryptic secondary metabolite pathways. In Antimicrobials, Antibiotic Resistance, Antibiofilm Strategies and Activity Methods; IntechOpen: Rijeka, Croatia, 2019; p. 119.

39. Euzéby, J. “Genus Streptomyces”. List of Prokaryotic Names with Standing in Nomenclature. 2008. Available online: http: / / www.bacterio.cict.fr/s/streptomycesa.html (accessed on 19 April 2021).

40. Waksman, S.A.; Henrici, A.T. The nomenclature and classification of the actinomycetes. J. Bacteriol. 1943, 46, 337. [CrossRef]

41. Bentley, S.D.; Chater, K.F.; Cerdeño-Tárraga, A.-M.; Challis, G.L.; Thomson, N.; James, K.D.; Harris, D.E.; Quail, M.A.; Kieser, H.; Harper, D. Complete genome sequence of the model actinomycete Streptomyces coelicolor A3 (2). Nature 2002, 417, $141-147$. [CrossRef] [PubMed]

42. Seipke, R.F.; Kaltenpoth, M.; Hutchings, M.I. Streptomyces as symbionts: An emerging and widespread theme? FEMS Microbiol. Rev. 2012, 36, 862-876. [CrossRef] [PubMed] 
43. Takahashi, Y.; Omura, S. Isolation of new actinomycete strains for the screening of new bioactive compounds. J. Gen. Appl. Microbiol. 2003, 49, 141-154. [CrossRef] [PubMed]

44. Sabido, E.; Tenebro, C.; Suarez, A.; Ong, S.; Trono, D.; Amago, D.; Evangelista, J.J.; Reynoso, A.; Villalobos, I.; Alit, L.; et al. Marine Sediment-Derived Streptomyces Strain Produces Angucycline Antibiotics against Multidrug-Resistant Staphylococcus aureus Harboring SCCmec Type 1 Gene. J. Mar. Sci. Eng. 2020, 8, 734. [CrossRef]

45. Demain, A.L. Small bugs, big business: The economic power of the microbe. Biotechnol. Adv. 2000, 18, 499-514. [CrossRef]

46. Watve, M.G.; Tickoo, R.; Jog, M.M.; Bhole, B.D. How many antibiotics are produced by the genus Streptomyces? Arch. Microbiol. 2001, 176, 386-390. [CrossRef] [PubMed]

47. Benizri, E.; Baudoin, E.; Guckert, A. Root colonization by inoculated plant growth-promoting rhizobacteria. Biocontrol Sci. Technol. 2001, 11, 557-574. [CrossRef]

48. Sylvia, D.M.; Fuhrmann, J.J.; Hartel, P.G.; Zuberer, D.A. Principles and Applications of Soil Microbiology; Pearson Prentice Hall: Upper Saddle River, NJ, USA, 2005.

49. Loliama, B.; Morinagab, T.; Chaiyanana, S. Biocontrol of Pythium aphanidermatum by the cellulolytic actinomycetes Streptomyces rubrolavendulae S4. Sci. Asia 2013, 39, 584-590. [CrossRef]

50. Costa, F.G.; Zucchi, T.D.; de Melo, I.S. Biological control of phytopathogenic fungi by endophytic actinomycetes isolated from maize (Zea mays L.). Braz. Arch. Biol. Technol. 2013, 56, 948-955. [CrossRef]

51. El-Tarabily, K.A.; Hardy, G.E.S.J.; Sivasithamparam, K. Performance of three endophytic actinomycetes in relation to plant growth promotion and biological control of Pythium aphanidermatum, a pathogen of cucumber under commercial field production conditions in the United Arab Emirates. Eur. J. Plant Pathol. 2010, 128, 527-539. [CrossRef]

52. Abreo, E.; Vaz-Jauri, P.; Nuñez, L.; Stewart, S.; Mattos, N.; Dini, B.; Altier, N. Pathogenicity of Pythium spp. obtained from agricultural soils and symptomatic legume seedlings in Uruguay. Australas. Plant Dis. Notes 2017, 12, 35. [CrossRef]

53. Küster, E.; Williams, S. Selection of media for isolation of streptomycetes. Nature 1964, 202, 928-929. [CrossRef]

54. Pepper, I.L.; Gerba, C.P.; Brendecke, J.W. Environmental Microbiology: A Laboratory Manual; Elsevier Science Press: London, UK, 2005.

55. Sanders, E.R. Aseptic laboratory techniques: Plating methods. J. Vis. Exp. 2012, e3064. [CrossRef] [PubMed]

56. Shahidi Bonjar, G.H.; Fooladi, M.H.; Mahdavi, M.J.; Shahghasi, A. Broadspectrim, a novel antibacterial from Streptomyces sp. Biotechnology 2004, 3, 126-130. [CrossRef]

57. El-Tarabily, K.; Soliman, M.; Nassar, A.; Al-Hassani, H.; Sivasithamparam, K.; McKenna, F.; Hardy, G.S.J. Biological control of Sclerotinia minor using a chitinolytic bacterium and actinomycetes. Plant Pathol. 2000, 49, 573-583. [CrossRef]

58. Zhang, Y.-P.; Uyemoto, J.; Kirkpatrick, B. A small-scale procedure for extracting nucleic acids from woody plants infected with various phytopathogens for PCR assay. J. Virol. Methods 1998, 71, 45-50. [CrossRef]

59. Cook, A.E.; Meyers, P.R. Rapid identification of filamentous actinomycetes to the genus level using genus-specific $16 \mathrm{~S}$ rRNA gene restriction fragment patterns. Int. J. Syst. Evol. Microbiol. 2003, 53, 1907-1915. [CrossRef]

60. Huang, X.; Madan, A. CAP3: A DNA sequence assembly program. Genome Res. 1999, 9, 868-877. [CrossRef] [PubMed]

61. Kumar, S.; Stecher, G.; Tamura, K. MEGA7: Molecular evolutionary genetics analysis version 7.0 for bigger datasets. Mol. Biol. Evol. 2016, 33, 1870-1874. [CrossRef]

62. Campanella, J.J.; Bitincka, L.; Smalley, J. MatGAT: An application that generates similarity/identity matrices using protein or DNA sequences. BMC Bioinform. 2003, 4, 29. [CrossRef]

63. Palaniyandi, S.; Damodharan, K.; Yang, S.; Suh, J. Streptomyces sp. strain PGPA39 alleviates salt stress and promotes growth of 'Micro Tom' tomato plants. J. Appl. Microbiol. 2014, 117, 766-773. [CrossRef]

64. Nonomura, H. Key for classification and identification of 458 species of the streptomycetes included in ISP. J. Ferment. Technol. 1974, 52, 78-92.

65. Kathiravan, P.; Sabarinathan, R.; Subbaiya, R.; Masilamani Selvam, M. Investigation on sugar cane field Actinomycetes of Erode District. Res. J. Pharm. Biol. Chem. Sci. 2016, 7, 1145-1154.

66. Hankin, L.; Anagnostakis, S.L. The use of solid media for detection of enzyme production by fungi. Mycologia 1975, 67, 597-607. [CrossRef]

67. Alström, S.; Burns, R.G. Cyanide production by rhizobacteria as a possible mechanism of plant growth inhibition. Biol. Fertil. Soils 1989, 7, 232-238. [CrossRef]

68. Gao, H.; Li, P.; Xu, X.; Zeng, Q.; Guan, W. Research on volatile organic compounds from Bacillus subtilis CF-3: Biocontrol effects on fruit fungal pathogens and dynamic changes during fermentation. Front. Microbiol. 2018, 9, 456. [CrossRef] [PubMed]

69. Jorjandi, M.; Bonjar, G.S.; Baghizadeh, A.; Sirchi, G.S.; Massumi, H.; Baniasadi, F.; Aghighi, S.; Farokhi, P.R. Biocontrol of Botrytis allii Munn the causal agent of neck rot, the post harvest disease in onion, by use of a new Iranian isolate of Streptomyces. Am. J. Agric. Biol. Sci. 2009, 4, 72-78. [CrossRef]

70. Kyuchukova, M.A.; Büttner, C.; Gabler, J.; Bar-Yosef, B.; Grosch, R.; Kläring, H.-P. Evaluation of a method for quantification of Pythium aphanidermatum in cucumber roots at different temperatures and inoculum densities. J. Plant Dis. Prot. 2006, 113, 113-119. [CrossRef]

71. Zheng, X.; Wang, J.; Chen, Z.; Zhang, H.; Wang, Z.; Zhu, Y.; Liu, B. A Streptomyces sp. strain: Isolation, identification, and potential as a biocontrol agent against soilborne diseases of tomato plants. Biol. Control 2019, 136, 104004. [CrossRef] 
72. Martinuz, A.; Schouten, A.; Sikora, R. Systemically induced resistance and microbial competitive exclusion: Implications on biological control. Phytopathology 2012, 102, 260-266. [CrossRef]

73. Parke, J.L. Root colonization by indigenous and introduced microorganisms. In The Rhizosphere and Plant Growth; Keister, D.L., Cregan, P.B., Eds.; Beltsville Symposia in Agricultural Research; Springer: Dordrecht, The Netherlands, 1991; Volume 4, pp. 33-42.

74. Evangelista-Martínez, Z.; Contreras-Leal, E.A.; Corona-Pedraza, L.F.; Gastélum-Martínez, É. Biocontrol potential of Streptomyces sp. CACIS-1.5CA against phytopathogenic fungi causing postharvest fruit diseases. Egypt. J. Biol. Pest Control 2020, $30,117$. [CrossRef]

75. Getha, K.; Vikineswary, S. Antagonistic effects of Streptomyces violaceusniger strain G10 on Fusarium oxysporum f. sp. cubense race 4: Indirect evidence for the role of antibiosis in the antagonistic process. J. Ind. Microbiol. Biotechnol. 2002, 28, 303-310. [PubMed]

76. Zhao, J.; Xue, Q.; Niu, G.; Xue, L.; Shen, G.; Du, J. Extracellular enzyme production and fungal mycelia degradation of antagonistic Streptomyces induced by fungal mycelia preparation of cucurbit plant pathogens. Ann. Microbiol. 2013, 63, 809-812. [CrossRef]

77. Viaene, T.; Langendries, S.; Beirinckx, S.; Maes, M.; Goormachtig, S. Streptomyces as a plant's best friend? FEMS Microbiol. Ecol. 2016, 92, fiw119. [CrossRef] [PubMed]

78. Ait Barka, E.; Vatsa, P.; Sanchez, L.; Gaveau-Vaillant, N.; Jacquard, C.; Klenk, H.-P.; Clément, C.; Ouhdouch, Y.; van Wezel, G.P. Taxonomy, physiology, and natural products of Actinobacteria. Microbiol. Mol. Biol. Rev. 2016, 80, 1-43. [CrossRef]

79. Huddleston, A.S.; Cresswell, N.; Neves, M.; Beringer, J.E.; Baumberg, S.; Thomas, D.I.; Wellington, E. Molecular detection of streptomycin-producing streptomycetes in Brazilian soils. Appl. Environ. Microbiol. 1997, 63, 1288-1297. [CrossRef] [PubMed]

80. Guo, Y.; Zheng, W.; Rong, X.; Huang, Y. A multilocus phylogeny of the Streptomyces griseus 16S rRNA gene clade: Use of multilocus sequence analysis for streptomycete systematics. Int. J. Syst. Evol. Microbiol. 2008, 58, 149-159. [CrossRef]

81. Gopalakrishnan, S.; Pande, S.; Sharma, M.; Humayun, P.; Kiran, B.K.; Sandeep, D.; Vidya, M.S.; Deepthi, K.; Rupela, O. Evaluation of actinomycete isolates obtained from herbal vermicompost for the biological control of Fusarium wilt of chickpea. Crop Prot. 2011, 30, 1070-1078. [CrossRef]

82. Shahidi Bonjar, G.; Barkhordar, B.; Pakgohar, N.; Aghighi, S.; Biglary, S.; Rashid Farrokhi, P.; Aminaii, M.; Mahdavi, M.; Aghelizadeh, A. Biological control of Phytophthora drechsleri Tucker, the causal agent of pistachio gummosis, under greenhouse conditions by use of actinomycetes. Plant Pathol. 2006, 5, 20-23. [CrossRef]

83. Yang, Y.; Wu, Z.-M.; Li, K.-T. The peculiar physiological responses of Rhizoctonia solani under the antagonistic interaction coupled by a novel antifungalmycin N2 from Streptomyces sp. N2. Arch. Microbiol. 2019, 201, 787-794. [CrossRef]

84. Cao, P.; Liu, C.; Sun, P.; Fu, X.; Wang, S.; Wu, F.; Wang, X. An endophytic Streptomyces sp. strain DHV3-2 from diseased root as a potential biocontrol agent against Verticillium dahliae and growth elicitor in tomato (Solanum lycopersicum). Antonie Leeuwenhoek 2016, 109, 1573-1582. [CrossRef] [PubMed]

85. Hamdali, H.; Hafidi, M.; Virolle, M.J.; Ouhdouch, Y. Growth promotion and protection against damping-off of wheat by two rock phosphate solubilizing actinomycetes in a P-deficient soil under greenhouse conditions. Appl. Soil Ecol. 2008, 40, 510-517. [CrossRef]

86. Goudjal, Y.; Toumatia, O.; Yekkour, A.; Sabaou, N.; Mathieu, F.; Zitouni, A. Biocontrol of Rhizoctonia solani damping-off and promotion of tomato plant growth by endophytic actinomycetes isolated from native plants of Algerian Sahara. Microbiol. Res. 2014, 169, 59-65. [CrossRef] [PubMed]

87. Loqman, S.; Barka, E.A.; Clément, C.; Ouhdouch, Y. Antagonistic actinomycetes from Moroccan soil to control the grapevine gray mold. World J. Microb. Biotechnol. 2009, 25, 81-91. [CrossRef]

88. Esmaeel, Q.; Jacquard, C.; Sanchez, L.; Clément, C.; Barka, E.A. The mode of action of plant associated Burkholderia against grey mould disease in grapevine revealed through traits and genomic analyses. Sci. Rep. 2020, 10, 19393. [CrossRef]

89. Michel-Aceves, A.; Díaz-Nájera, J.; Ariza-Flores, R.; Otero-Sánchez, M.; Escobar-Martínez, R.; Avendaño-Arrazate, C. Control Alternatives for Damping-Off in Tomato Seedling Production. Phyton 2019, 88, 325-333. [CrossRef] 